\title{
韓国の集合住宅における個別要求に対応した住戸改造に関する実態研究 A STUDY ON ACTUAL CONDITION OF CUSTOMIZATION OF DWELLING ON THE APARTMENTS IN SOUTH KOREA
}

\author{
丁 志 映*, 李 東 昱**, マリアンネコスタ***, 藤本秀一 $* * * *$ \\ 米野史健 ${ }^{* * * * *}$, 小林秀樹****** \\ Jiyoung JUNG, Dong-Wook LEE, Costa MARIANNE, \\ Hidekazu FUJIMOTO, Fumitake MENO and Hideki KOBAYASHI
}

\begin{abstract}
The purpose of this study is to investigate the actual nature of the customization of apartments in South Korea and the usage of interior components and industrialization in these dwellings.

The results are summarized as follows.

1) The residents did work in the customization period in all three stages of occupancy of their unit. 2) The scale of the customization work and the skill of workers performing them differed by construction stage. 3) The assembly of furniture and equipment such as a system kitchen is progressing. But craftsmen commonly intervened in the final stages of work.
\end{abstract}

Keywords : Customization, Infill, Work period, Open building, Apartment, South Korea 個別要求対応，インフィル，工事段階，SI 住宅、集合住宅，韓国

\section{1. 研究の背景と目的}

2010 年現在、韓国の全住宅ストック数は 14677 千戸であり、こ のうち、共同住宅は 7 割を超えている注1)。特に、5 階建て以上のア パートは共同住宅の中でも 8 割以上を占めている注 2$) 。 1980$ 年時点 において、単独住宅の $87.5 \%$ に対してアパートが $7 \%$ に過ぎなかっ た事実を考慮すると、韓国の住宅形式が急速に集合住宅中心に移り つつあることがわかる。

これらの共同住宅ストックの急増と老朽化の加速化とともに、韓 国住宅市場を主導してきた建替えは、個人投資家やアパート所有者 たちの過剩な投機により住宅価格の高騰を呼ぶ等、多くの社会問題 を引き起こしたため、2001年以降から政府は「建築法施行令」の改 正を通じて建物の骨組みを残して全面的な大規模改修を行うリモデ リング注3) を推奨している。リモデリングの対象住戸はバルコニー の新設および拡張が可能であるため、既存の容積率には影響を与え ず、使用面積の拡大効果を得ることができるようになった注4)。

さらに、2005 年 12 月 2 日「建築法施行令」の改正によりバルコ ニーは必要によって居室・寝室・倉庫等の用途で使用できるように なり、住戸のバルコニー拡張工事が合法化された。これらにより居
住者個人による住戸の拡張等のカスタム行為がより活発に行われる と予想される。

住戸における個別要求対応に関連する韓国の既往研究としては、 2006 年のバルコニー拡張の合法化前の研究ではアパートのバルコ ニーの利用実態と満足度を調査してそれらの結果に基づきバルコニ 一の面積、形態、床材等の改善案を提示する研究が多く注 5)、2006 年以降の研究ではバルコニーの拡張有無による居住者の空間の使わ れ方文2)・6)、設計コンペの当選図面のバルコニー拡張形態の分析文 3)・4)、拡張型バルコニーの満足度調査文5) 等がある。一方、日本で は新築時の個別要求対応に着目した、江袋聡司らによる民間分譲集 合住宅におけるフリープランに関する研究文7) や沢田知子らによる フリープラン賃貸住宅の住まい方変化に関する研究文8) 等があり、 集合住宅における入居後のリフォームに関する研究は多く行われて いる文9) 13)。しかし、日韓両国において集合住宅の新築時の入居前・ 後を含む全ての工事段階に着目し、居住者宅に直接訪問してヒアリン グ調査や実測調査を行い、住戸に対する個別要求傾向について論じた 既往研究は筆者らが知る限りではほとんどない。

韓国では、日本と比べて(1)アパートの新築段階の入居前に住戸内

\footnotetext{
本論文は, $2012 \cdot 2013$ 年度日本建築学会大会 (東海・北海道)で発表した内容を，加筆・修正したものである文15)-17)。 * 千葉大学大学院工学研究科建築・都市科学専攻 助教・学博

** 非常勤教師 · 工博

*** 千葉大学大学院工学研究科建築 · 都市科学専攻 博士後期課程 ·工修

**** 国土交通省国土技術政策総合研究所 室長 ·工修 国土交通省国土技術政策総合研究所 主任研究官·工博 千葉大学大学院工学研究科建築・都市科学専攻 教授・工博 
の個別要求に対応するのが一般的である。一方、(2)工業化した内装 部品が受け入れられていないことが特徵である。また、(3)バルコニ 一部拡張の合法化により容積率の許容範囲、境界部の意思決定、避 難経路等、共用部の扱いが特殊になった。そのことから日韓の公法 と私法の比較による SI(スケルトン・インフィル)の再区分が求めら れる。そこで、本稿では研究成果の第 1 報として上記の (1) と (2)につ いての実態と理由を究明する。(3)については第 2 報で明らかにする。

\section{2. 調査概要}

韓国の第 1 次調查 $(2011.9 .14 \sim 20)$ と第 2 次調查（2011.10.13～ 16）では、ソウル市と仁川新都市のアパート 34 件に対して、住戸 の個別要求実態、バルコニー拡張等についての居住者へのヒアリン グ調査、実測による図面作成、住戸と団地内のカメラ・ビデオ撮影 等を行った。また、関連団地の管理事務所所長に対して管理全般、 バルコニー拡張等の手続きや計画修絟等についてヒアリングを行っ た。さらに、第 3 次調查 $(2012.2 .21 \sim 27)$ では、施工社、設計事務 所、インテリア会社・個人業者に、工事内容や問題等についてヒア リングを実施した。1 次調査では、比較的漢江(Han-gang)に近く、 住戸面積が広いものを、2 次調査では、漢江から離れた住戸面積が 狭いものを対象に幅広く調查事例を選定した（図 1 -写真 1 )。建築 年ごとの事例概要と個別要求の工事情報等は図 2 に示寸。

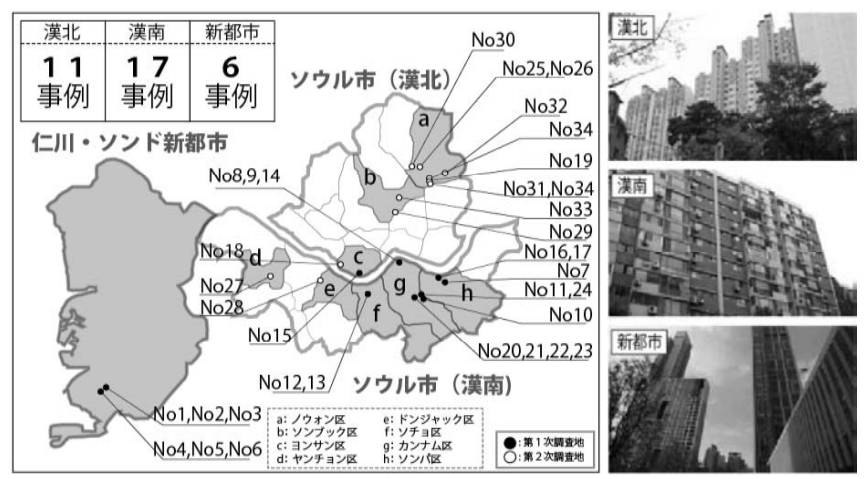

図 1 調査事例の立地

写真 1 事例アパートの外観

\section{3. 事例にみる住戸の工事段階}

\section{3-1. 住戸における入居者の個別要求時期}

（1）３段階による住戸の個別要求工事 (施工社へのヒアリングにより)

アパートの各住戸の個別要求工事には 3 つに分類することができ る(図 3 )。(1)施 工社（建設業者）

によるオプショ ン工事 (竣工注 7 ) まで)、(2)引渡前 のインテリア会 社や個人業者に よる工事（引渡 前)、(3)入居後の

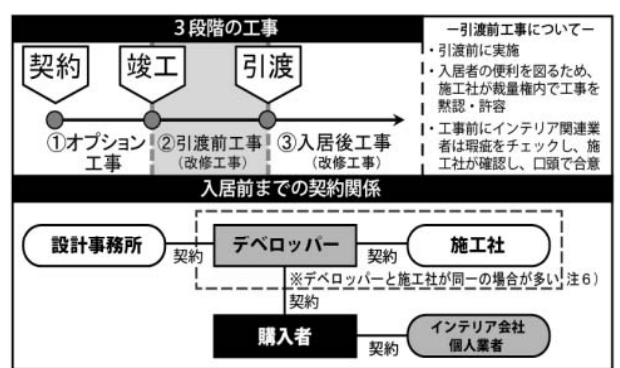

図 3 ３段階の個別要求工事時期の仕組み
インテリア会社や個人業者による工事がある。

(1)竣エ前のオプションエ事

オプション工事とは、デベロッパー（施行社）注8) または、施工 社が提供する方式である。一般的に間取りの変更ではなく、「バルコ

ニーの拡張」や「造付家具の設置」、高級な「壁の装飾」等の用意さ れたオプション仕様の中から選択する形式である。契約時の段階で バルコニー拡張等の比較的大きな変更のオプション工事の契約をす る。躯体工事が完了し、竣工に近い段階で、内装の仕上げに関連す る契約を行うことができる。バルコニー拡張合法化前は、仕上げに 関連する業務がほとんどであった。

\section{(2)新築段階の引渡前工事}

竣工後から引渡までの間に行われる内装工事で、住宅購入者が別 途インテリア会社や個人業者（以降、工事業者） 一発注・工事寸る 方式である。この方式が定着している理由としては、(1通常、韓国 のアパート団地は超高層で規模が大きく、契約から竣工まで通常 2 年から 3 年かかる。そのために、契約時に選んだ内装仕様に要求変 更が生じる。2内装工事費が安価であるため、やり直し工事をしても 負担が少ない。3一斉工事をするため、騒音を避けることができる等 の理由が挙げられる。

施工社の立場からみると、引渡後に個別工事をするのが望ましい。 しかし、引渡と同時に居住者の個別要求に合った住宅で住める等、 入居予定者への便利を図るために、引渡前期間の $1 \sim 2$ ヶ月の間に 施工社の裁量権内で個別工事を暗黙に許容している注9)。その代わ りに施工社は内装等の工事に対する誓約書・覚書等の書類を用意し、 問題が発生しないように文書で根拠を作っておく等の工夫をしてい る。特に、この工事時期の調整役割は施工社が行っている。これら の役割は管理事務所注10) が主体になって実施するのが望ましいが、 管理事務所の体制が整っていなくて、工事全体をコントロールでき ないため、通常施工社が管理をしている状況である。

工事時の管理部分（工事車両の駐車・管理・許可、足場設置、ゴミ 等）については、費用と絡んでいるため、管理事務所が管理し、工事 業者は保証金を支払い、工事許可書をもらって施工社に提出する手順 になっている。

工事時の瑕疪の責任については、業者は工事前に傷等のチェックを して施工社にリストを提出する。しかし内装工事後、工事業者による 瑕疪が頻繁に発生している。特に默認された工事だと、施工社に責任 を押付ける業者が存在することから、内装工事前に施工社がチェック リストで対象住戸の状況を確認する。しかし業者の不法工事を黙認し ているため、書面ではなく口頭で対応を行っている。

\section{(3)新築・中古の入居後工事}

新築および中古購入後に行われる内装工事で、購入者または賃借 人が個別にインテリア会社や個人業者へ発注する方式である。入居後 工事をさらに細かく分類し、新築購入者による引渡後の工事と中古購 入者または賃借人による入居前工事を『入居後工事 I』、現入居者に よる入居後工事を『入居後工事 II 』をす。

\section{（2）事例住戸の属性}

（1)住居属性（図 2·表 1)

表 1 住戸面積と家族構成

調查住戸は、持ち 家が 17 件、韓国式賃 貸（チョンセ注11）以 下賃貸)が 17 件あり、 その中でも別宅を持 ちつつ賃借している 事例が 7 件あった。

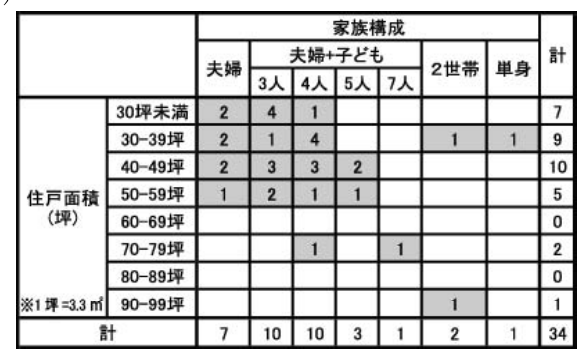


1970 年代建築 ( 3 団地 5 事例)

\begin{tabular}{|c|c|c|c|c|c|c|}
\hline \multirow{4}{*}{ 团地 } & 國地№. & \multicolumn{3}{|c|}{ (4) } & (15) & (20) \\
\hline & 団地名 & \multicolumn{3}{|c|}{ 江南区Gu國地 } & 城北区De可地 & 龍山区Shi可地 \\
\hline & 建築年 & \multicolumn{3}{|c|}{ 1979年 } & 1972年 & 1970年 \\
\hline & 築年数 & \multicolumn{3}{|c|}{ 34年 } & 39年 & 41年 \\
\hline \multirow{4}{*}{ 住戸 } & 事例No. & 8 & 9 & 14 & 29 & 18 \\
\hline & 所有形態 & $0^{中}$ & $i^{p}$ & $0^{中}$ & 86 中 & in \\
\hline & 入居年 & 2009年 & 1996年 & 2007年 & 2010年 & 2009年 \\
\hline & 居住年数 & 2年 & 15年 & 4年 & 1年 & 2年 \\
\hline \multirow{4}{*}{$\begin{array}{l}\text { 工事 } \\
\text { 情報 }\end{array}$} & 改修年 & $\begin{array}{c}\begin{array}{c}\text { 不明 } \\
\text { 2009年 }\end{array} \\
\end{array}$ & 1996年 & 不明 & 不明 & 2011年 \\
\hline & $\frac{\text { オプション }}{\text { 引渡前 }}$ & \multirow[t]{2}{*}{ 不 } & & \multirow[t]{3}{*}{ 不 } & \multirow[t]{2}{*}{ 不 } & \\
\hline & 入居後1 & & & & & \\
\hline & 入居後2 & 利 & (所) & & 利 & 所 \\
\hline
\end{tabular}

1980 年代建築（3 団地 4 事例）

\begin{tabular}{|c|c|c|c|c|c|}
\hline \multirow{4}{*}{ 圈地 } & 団地№. & (5) & \multicolumn{2}{|c|}{ (7) } & (13) \\
\hline & 団地名 & 江南区So団地 & \multicolumn{2}{|c|}{ 瑞草区Ba団地 } & 陽川区Mo団地 \\
\hline & 建築年 & 1983年 & \multicolumn{2}{|c|}{ 1983年 } & 1988年 \\
\hline & 築年数 & 28年 & \multicolumn{2}{|c|}{ 28年 } & 23年 \\
\hline \multirow{4}{*}{ 住戸 } & 事例No. & 10 & 12 & 13 & 27 \\
\hline & 所有形態 & & & 8 & in \\
\hline & 入居年 & 2010年 & 2001年 & 2004年 & 2007年 \\
\hline & 居住年数 & 1年 & 10年 & 7年 & 4年 \\
\hline \multirow{5}{*}{ 情事報 } & 改修年 & 2010年 & $\begin{array}{l}\text { 1998年 } \\
\text { 2005年 }\end{array}$ & 2001年 & 2007年 \\
\hline & オプション & & & & \\
\hline & 引渡前 & & & & \\
\hline & 入居後1 & 所 & (所) & (所) & \\
\hline & 入居後2 & & 所 & & (所) \\
\hline
\end{tabular}

1990 年代建築 (4 団地 6 事例)

\begin{tabular}{|c|c|c|c|c|c|c|c|}
\hline \multirow{4}{*}{ 団地 } & 団地No. & \multicolumn{2}{|c|}{ (6) } & (8) & \multicolumn{2}{|c|}{ (12) } & (17) \\
\hline & 団地名 & \multicolumn{2}{|c|}{ 江南区De國地 } & 龍山区Ga団地 & \multicolumn{2}{|c|}{ 应原区Wo國地 } & 蕰原区Du团地 \\
\hline & 建策年 & \multicolumn{2}{|c|}{ 1999年 } & 1998年 & \multicolumn{2}{|c|}{ 1992年 } & 1998年 \\
\hline & 策年数 & \multicolumn{2}{|c|}{ 12年 } & 13年 & \multicolumn{2}{|c|}{ 19年 } & 13年 \\
\hline \multirow{4}{*}{$\begin{array}{l}\text { 住戸 } \\
\text { 情報 }\end{array}$} & 事例No. & 11 & 24 & 15 & 25 & 26 & 31 \\
\hline & 所有形態 & & 8 & 8 & & if & 8 中 \\
\hline & 入居年 & 2009年 & 2010年 & 2000年 & 2010年 & 2003年 & 2010年 \\
\hline & 居住年数 & 2年 & 1年 & 11 年 & 1年 & 8年 & 1年 \\
\hline \multirow{5}{*}{$\begin{array}{l}\text { 工事 } \\
\text { 情報 }\end{array}$} & 改修年 & 2003年 & $\begin{array}{c}\text { 不明 } \\
\text { 2010年以降 }\end{array}$ & $\begin{array}{l}\text { 2000年 } \\
\text { 2011年 }\end{array}$ & 2010年 & 2003年 & 不明 \\
\hline & オプション & & \multirow{3}{*}{ 不 } & & & & \multirow{3}{*}{ 不 } \\
\hline & 引渡前 & & & (所) & & & \\
\hline & 入居後1 & 所) & & & & & \\
\hline & 入居後2 & & 利 & 所 & 利 & 所 & 利 \\
\hline
\end{tabular}

2000 年代建築 (11 団地 19 事例)

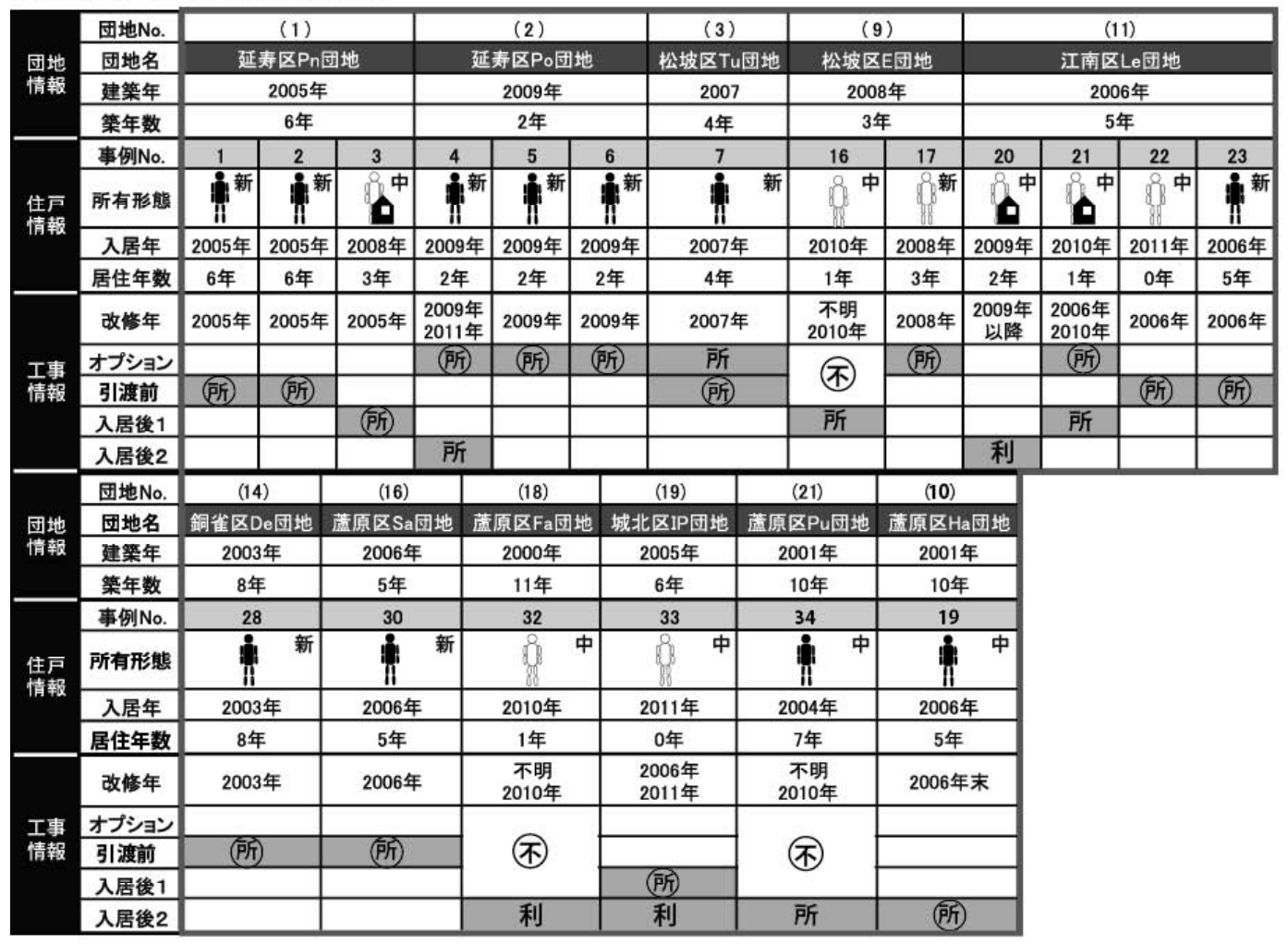

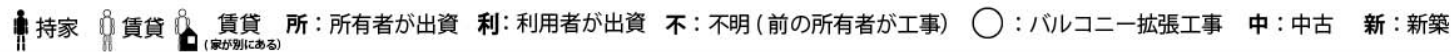
図 2 建築年ごとの事例概要と個別要求の工事情報 
築年数は「 2 年から 30 年」、居住年数は「 1 年に満たないものから 15 年まで」である。住戸面積は「30～50 坪」、家族構成は「夫婦+子ど も」が多く、3〜 人暮らす事例が多かった。

\section{(2)居住年数と定住意識}

持ち家では、6 割の居住者が定住を希望している。賃貸では、別 宅を持たない世帯では、3 割が定住を意識しているのに対して、別 宅を持つ世帯の中では、「子どもが大きくなるまで」等、家族のライ フスタイルに合わせた住環境を選択していた。住戸の引越しの理由 としては、所有形態に関係なく、「子どもの教育のため」(34 中 14 件）という意見が多かった。

\section{(3)個別要求の工事時期と工事実施主体（図 2)}

持ち家に着目すると、「建築年」「新築・中古」に関係なく、入居 後 3 年以内に工事している事例が多かった。事例 12 では、住戸が 古いため以前の所有者が工事して売却し、入居後に現所有者が再び 工事を行っている。事例 15 では、所有者が工事して賃貸住戸とし て貸し出し、再び入居後に工事している。賃貸事例では、ほとんど の住戸で賃貸化する前に所有者によって改修工事が行われている。 また、賃借人が入居の際に改修工事を行う事例が多い (17 中 8 件)。 事例 17 は、新築のまま賃貸化を行った事例である。

全ての工事時期、工事実施主体が明確である持ち家・新築に着目 すると、事例数は計 10 件（No.1,2,4,5,6,7,15,23,28,30）あり、その うち 9 件の事例で「オプション工事」または「引渡前工事」の段階 で工事を行っている。事例 4 と事例 15 の 2 件は入居後にさらに工 事を行っている。また、持ち家・新築でさらに 2006 年以降バルコ ニーの拡張工事を行っている事例は計 6 件あり、「オプション工事」 で拡張を行っている事例は 3 件、「引渡前工事」で拡張を行っている 事例は 3 件である。また、新築・持ち家で 2005 年以前に拡張工事 を行っている事例は計 4 件あり、いずれも「引渡前工事」で拡張工 事を行っており、入居後に拡張を行っている事例はない。

\section{3-2. 住戸の個別要求時期による工事傾向}

各工事段階別の所有形態を分類すると、図 4 のようになる。オプ ション工事の事例は 6 件、 引渡前工事の事例は 8 件、 入居後工事 $\mathrm{I}$ の事例は 8 件、入居後工事 II $の$ 事例は 17 件である。そのうち、2 回工事を行った事例が 6 件 あった。他の工事段階と比 べて入居後工事では、賃貸 において工事が多くみられ る。なお、賃貸にオプション

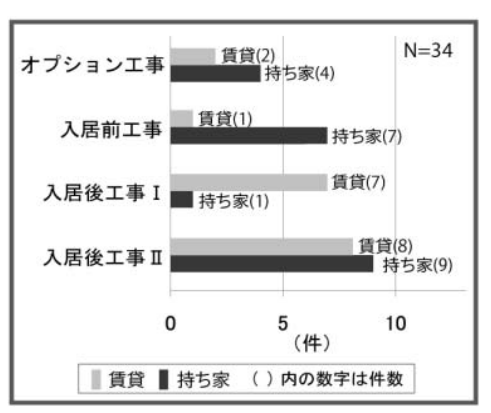

図 4 3 段階別の所有形態件数
工事や引渡前工事があるのは、賃借人が実施したのではなく、所有 者が工事を行い、その工事内容を賃借人が把握しているからである。 (1) 竣工前のオプションエ事（図 2 、図 4 、表 2 の参照)

オプション工事では、持ち家が 4 件、賃貸が 2 件である。工事実 施者はいずれも所有者である。全て 2006 年以降建設されたアパー トで、事例 21 は合法化後初めて建設された事例である。工事時期 をみると、オプション工事のみを行った事例が 3 件、オプション工 事と引渡前工事を行った事例が 1 件 (No.7)、オプション工事と入居
後工事を行ったものが 2 件（No.4，21）該当した。工事範囲をみる と、共用イ

ンフィルで あるバルコ ニーの工事 が多く、工 事内容をみ ると「バル コニー拡張 工事」や、そ れに伴う 「建具や間 事例 4 (持家・新築)

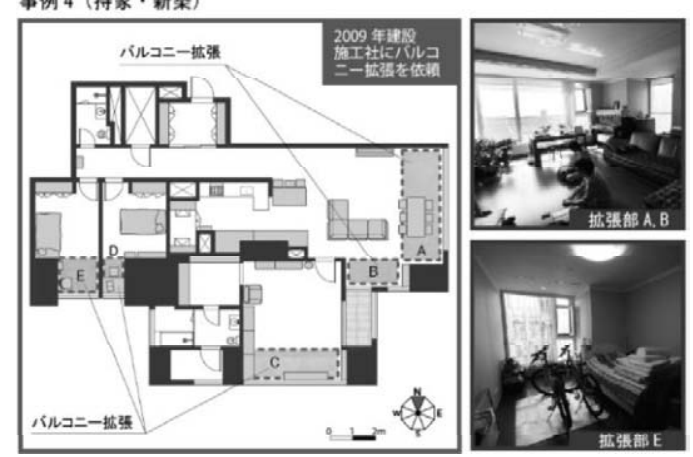

図 5 オプションエ事の事例

仕切りの設置」「仕上げの変更」が目立っている。

（2）新築段階の引渡前工事（図 2、図 4、表 2 の参照)

引渡前工事では、持ち家が 7 件、貨貸が 1 件である。工事実施者 はいずれも所有者である。事例 $22 、 23$ は合法化後初めて建設され たアパートである。工事時期をみると、入居前工事のみを行った事 例が 6 件、オプション工事と引渡前工事を行った事例が 1 件 (No.7)、 引渡前工事 事例 1 (持家・新筑)

と入居後工 事を行った ものが 1 件

( No.15) 該当した。

オプショ

ン工事と比

ベて工事範

囲は、専有 部分の仕上
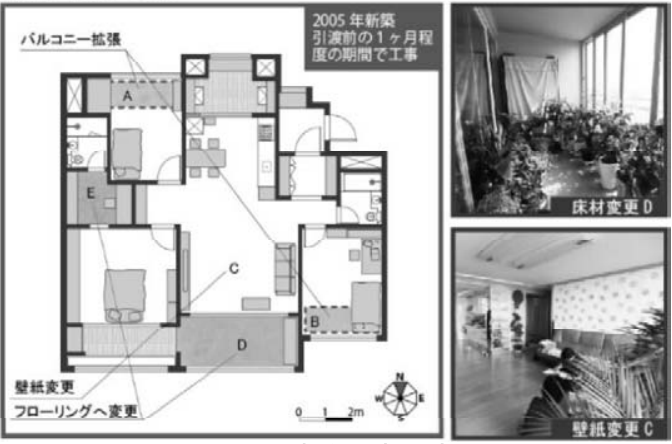

げや設備等にまで広がっており、比較的幅広く工事を行っている傾向 がみられる。具体的な内容をみると、「バルコニー拡張」とともに「壁 紙の変更」や「床暖房の設置」「タイル交換」等、表装の現場施工のも のが多い。

（3）入居後工事 I（図 $2 、$ 図 4、表 2 の参照)

入居後工事 I では、持ち家が 1 件、賃貸が 7 件である。この段階 の工事は、事例 12 のように改修を行って、住戸価值を上げ『投資』 を目的として売却する事例や、事例 10、16、21 のような現所有者 が貨貸する前に 事例 12 (持家・中古) 工事を行い、住戸 の付加価值を上 げている事例が みられた。

改修範囲をみ ると、バルコニー から専用インフ イル部まで幅広 く改修を行って いることが分か

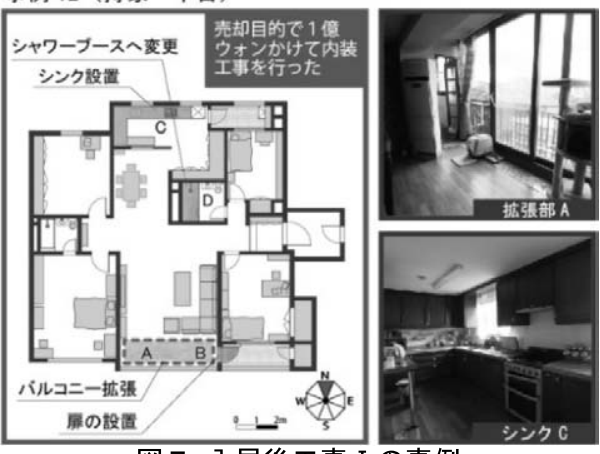

図 7 入居後工事 I の事例
る。工事は「バルコニー拡張」、「建具の交換」、「仕上げ材の交換」 が多く、次いで「水回りの設備・部品の交換」や「家具の設置」等 
事例 33 (賃貸· 中古)

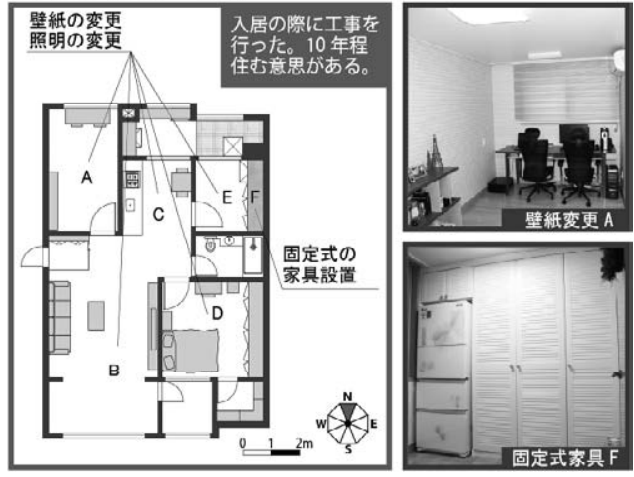

図 8 入居後工事 II の事例

が多い。

事例 12 は、現所有者が家を購入する 3 年前に 前所有者が住戸を売り出すことを考え、1 億ウ オンかけて内装工事を行った。その内装費用は 住戸の売り出し価格に上乗せしているので、同 アパート内の同じ間取りの住戸に比べて高い価 格で取引された。

(4) 入居後工事 II (図 2、図 4、表 2 の参照)

入居後工事 II では、持ち家が 9 件、賃貸が 8 件である。工事内容をみると、他の工事段階と 比べて「バルコニー拡張」が少なく、主に「仕上 げ」やシンク、便器、洗面台、浴槽の交換等の 「水回りの設備・部品の交換」「家具の設置」で あった。さらに「建具の交換」や「照明の変更」 等の工事も多くの事例でみられる。中古の場合、 現居住者のライフスタイルや趣味に合わせた工事が多く、押入や 棚の設置等の家族の変化に伴う工事が目立っていた。

貨貸では、賃借人の費用負担による工事が行われており、専用イ ンフィル部を重点的に行っていることが分かる。改修内容をみる と、「仕上げ材の変更」「家具の設置」がほとんどではあるが、「水回 りの設備・部品の交換」や「照明の変更」も行われている。利用者 が自らの生活に合わせて活発な改修行為を行っていることと考え られる。この段階の工事は、持ち家、賃貸ともに現居住者自身の負 担で改修工事を行うため、『ライフスタイルに合わせる手段』の側 面が大きいといえる。

\section{4. 事例にみるインフィル部の工業化の実態} 4-1. 家具の分析

\section{(1) 家具の分類}

家具について「建築と一体化しているか」・「家具として自立して

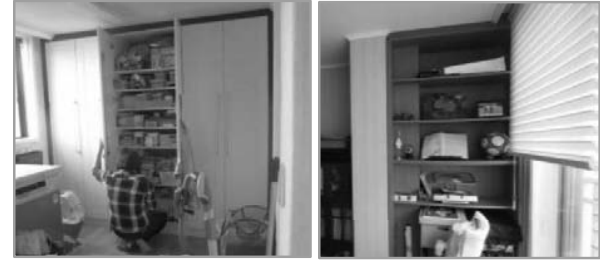

写真 2 造付家具 (No. 13, 15)
いるか」に着目し、 大きく 3 つに分 類した (図 9 )。家 具自体で自立す る『移動容易家 具』、部材で隙間 が埋められ、固定
されているものを『寸法調整家具』、建築の一部が家具を構成してい

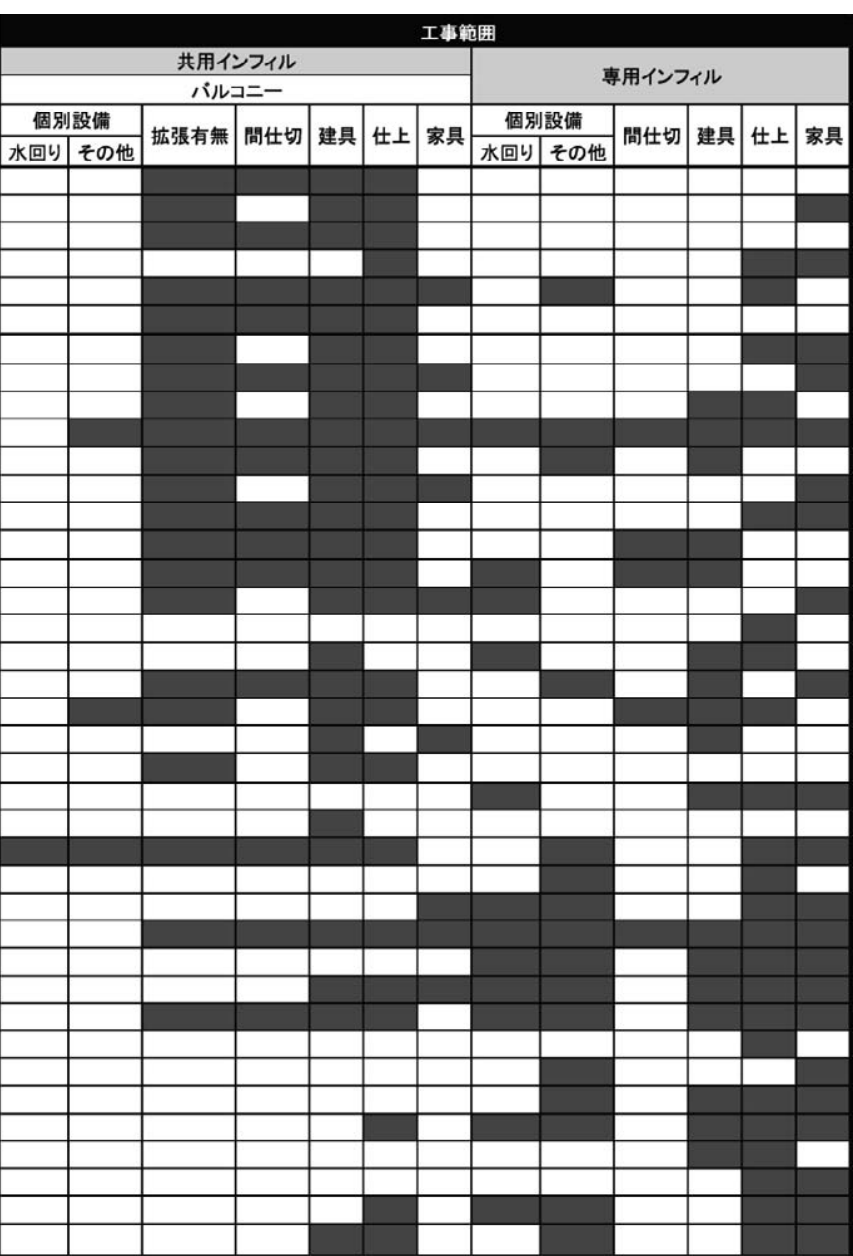

家具 1394 個 / 34 住戸

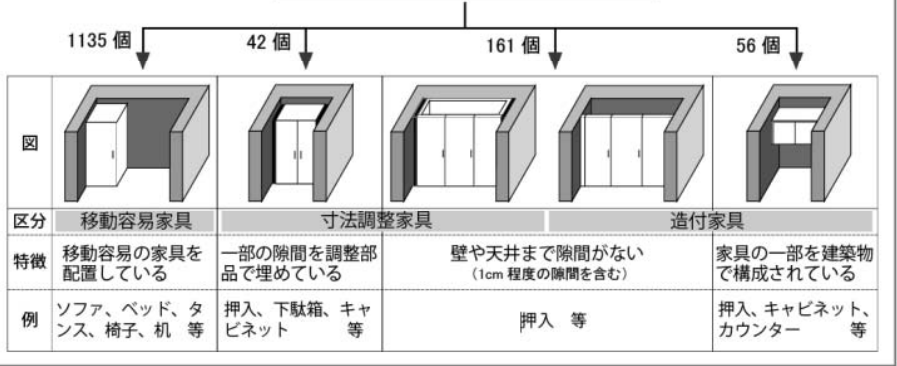

図 9 家具の分類

るものを『造付家具』とした。ただし本調査では、内部を確認でき ていない家具もあり、『寸法調整家具』と『造付家具』の判別が困難 であるものは別に分類した。

調査住戸 34 件の中で、確認できる家具は 1394 個あり、『移動容 易家具』が 1135 個、『寸法調整家具』が 42 個、『造付家具』が 56 個、建築と家具の隙間が全部埋められたものが 161 個あった。その 中で壁や天井まで隙間がない家具に着目すると、1住戸当たり平均 4.7 個となる。

(2) 家具の納まりに着目した分析

続いて前項で分類した「全面隙間がない家具 (161 個)」の建築と の「納まり」に着目して分類を行う（図 10 ・表 3 )。隙間を埋める ための調整部品の仕上がりをみることで、現場施工で仕上げられて いるのか、工場生産品で仕上げられているのかを明らかにする。 
表 3 家具の納まりに着目した分類項目

\begin{tabular}{|c|c|c|c|c|c|c|}
\hline \multirow[b]{2}{*}{ 現場or工場 } & \multirow[b]{2}{*}{ 家具の種類 } & 納めフレーム & 徽々た & 家具 & \multirow[b]{2}{*}{ 墡細 } & \multirow[b]{2}{*}{ グループ } \\
\hline & & 有O／無 $\mathrm{x}$ & 有O／無 $\times$ & $\begin{array}{c}\text { オーダーメイド } \\
\text { or既裂品 }\end{array}$ & & \\
\hline \multirow{10}{*}{$\begin{array}{c}\text { 職人の作業 } \\
\text { (クルーブ円ー }\end{array}$} & \multirow{4}{*}{ 収納 } & \multirow{3}{*}{0} & \multirow{3}{*}{$x$} & オーダーメイト & $\sim$ & (1) \\
\hline & & & & 不明 & 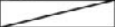 & 2 \\
\hline & & & & 既製品 & 寸法調整家具 & 3 \\
\hline & & $\underline{-}$ & & 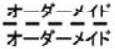 & $=$ & $-\frac{9}{1}-$ \\
\hline & \multirow{3}{*}{ 化粧台 } & \multirow[t]{2}{*}{0} & \multirow{3}{*}{$x$} & 不明 & 1 & 2 \\
\hline & & & & 睌梨品 & 寸法湅整家县 & 3 \\
\hline & & $x$ & & オニターメ任 & & $-\frac{1}{\sqrt[1]{1}}-$ \\
\hline & \multirow{3}{*}{ 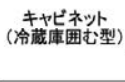 } & \multirow[t]{2}{*}{0} & \multirow{3}{*}{ « } & 不明 & 12 & 2 \\
\hline & & & & 既製品 & 寸法調整家具 & 3 \\
\hline & & $x$ & & オーダーメイド & 1 & 1 \\
\hline 萧者の取付作菜 & 収納 & 으. & - & - 既製品 & 寸法調整家具 & _- 4 \\
\hline$($ (クループ) & 化粧台 & 0 & 0 & 既翋品 & 寸法調整家具 & 4 \\
\hline
\end{tabular}

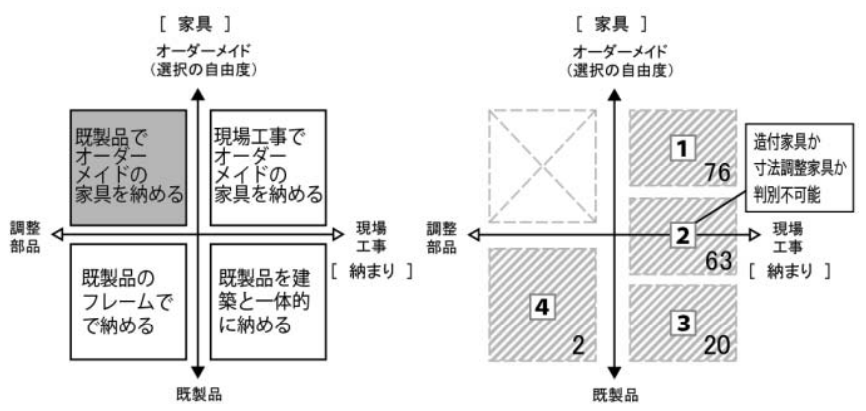

図 10 家具の納まり別の分類（右：グループロ〜鸟）注12）

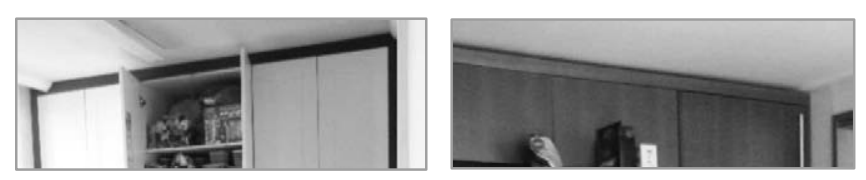

写真 3 職人の手による納め (No. 13) ·工業部品による納め (No. 23)

分類の結果、図 10 のように現場で納めているものは 159 個（グ ループロ・回・目の合計）に対して、工場生産品で納めているものは 2 個（グループ舟）であった。事例 13 の壁面収納の納め（グループ 回）は、天井と壁の間のモルディング (鋳造)に沿って形状を切り 出しており、現場施工で行っている。一方、事例 23 (グループ囵) の壁面収納の納めは、上部に $1 \mathrm{~cm}$ 程のスキマが生じており、寸法調 整の部品で納めている。

家具については、造付家具だけではなく、既存の家具でも、隙間 なく納める傾向が多い。また、運搬業者が取り付けるのではなく、 技術を持った職人が家具の「納まり」まで関与しているということ がわかった。

\section{4-2. 設備の分析}

調査住戸の「水回り設備」に着目し、部品化の傾向を分析する。

(1) 水回り設備の工事内容（表 4)

持ち家、賃貸ともに、「バスユニットを撤去し、シャワーブースー

\begin{tabular}{|c|c|c|c|c|c|c|c|c|}
\hline \multirow{3}{*}{\multicolumn{2}{|c|}{ 表 4 水回り設備の工事 }} & \multirow{2}{*}{\multicolumn{2}{|c|}{ 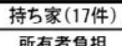 }} & \multicolumn{5}{|c|}{ 貿筫 (17件) } \\
\hline & & & & \multicolumn{2}{|c|}{ 所有者負担 } & \multicolumn{2}{|c|}{ 利用者負担 } & \multirow{2}{*}{ 不明 } \\
\hline & & 新第 & 中古 & 新築 & 中古 & 新勧 & 中古 & \\
\hline \multirow{2}{*}{ 浴䏆 } & 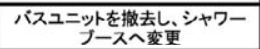 & 0 & 4 & 0 & 1 & 0 & 2 & 1 \\
\hline & $\begin{array}{c}\text { 浴摽の変更 } \\
\end{array}$ & 0 & 1 & 0 & 0 & 0 & 0 & 0 \\
\hline 洗面台 & 洗面台の後更 & 0 & 3 & 0 & 0 & 0 & 0 & 0 \\
\hline 便所 & 便器の変更 & 0 & 5 & 0 & 0 & 0 & 0 & 0 \\
\hline シンク & シンク台の交换 & 0 & 7 & 0 & 1 & 0 & 1 & 2 \\
\hline \multirow{3}{*}{ その他 } & 排水管を变更 & 0 & 1 & 0 & 0 & 0 & 1 & 0 \\
\hline & IH付きキッチンカウンターの設置 & 0 & 1 & 0 & 0 & 0 & 0 & 0 \\
\hline & タイルの交换 & 1 & 6 & 0 & 1 & 0 & 1 & 0 \\
\hline
\end{tabular}

変更」する工事が多かった。その他に「洗面台」や「便器」、「シン ク」の交換が多くみられた。

新築における水回り設備の工事は少なく、中古での改修がほとん どであった。これは、設備の老朽化や、以前の人が利用していたも のが現居住者に合っていない、もしくは、衛生面での配慮等が要因 であると考えられる。

\section{(2) 台所における部品化の傾向}

対象住戸 34 件全てでシステムキッチンが採用されており、シン クの工業化は進んでいる。台所の工 事は 29 件行われており、その中でシ ンクの交換を行っている事例は 11 件あった。事例 15 では、シンクの交 換の他にオーダーメイドで IH コン 口付きキャビネットを設置するな ど、積極的な台所回りの改修がみら れた (写真 4 )。

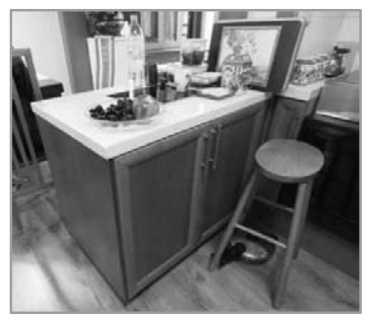

また、キッチン業者へのヒアリングによると、現在ではシステム キッチンのオプションだけではなく、各住戸の幅に合わせてオーダ ーメイドできる「インテリジェンスキッチン」タイプのニーズが増 えている。現場ではメーカーから依頼された業者がキッチンの大き さ、スイッチ・配線等の位置を正確に計測し、それに合わせパネル を切断する等、職人の手が介入していることがわかる。

(3) 浴室における部品化の傾向

対象住戸 34 件中、浴室が 1 つのものは 7 件、 2 つのものは 26 件、 $3 つ の も の は ~ 1$ 件該当した。浴室が 2 つるる住戸では、 1 つは玄関 からすぐにアクセスできる浴室、もう 1 つは夫婦の寝室からアクセ スできる浴室であった。浴室を改修し ている事例は 15 件で、そのうち 9 件が 「床や壁のタイル交換」を行っている。 また、既存のバスユニットをシャワー ブースー変更した全ての事例で、浴槽 に体を浸けることはほとんどなく、浴 槽の中で体を洗うことが多いために、

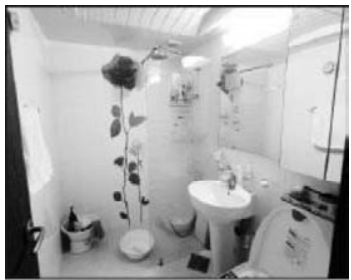

写真 5 タイル交換 (No. 19) 場所の有効活用を工事理由として挙げられた。

全ての住戸の浴室にはトイレが併設されており、在来工法で仕上 げられていた。つまり仕上げに対して職人の手が介入している。また、 日本のように「ユニットバス」は普及していないことがわかった。

\section{4-3. インフィル部の部品化と所得格差の関係}

本調査の結果を踏まえると、インフィル部の部品化の成立要因に は、『所得』が一部関連することが推測される。韓国において、全国 の賃金労働者の月収データをみると、所得格差が大きいことがわか る。大工やタイル職人の月収は、ソウル市の平均月収に比べて低く、 中間層が職人に工事を依頼することが金銭的に容易であることがう かがえる。また、今回の調査より、例えば同じ広さの部屋のバルコ ニー拡張時の所要費用をみると、個人業者によって費用の高いもの (事例 $7: 320$ 万ウォン) から低いもの（事例 28：130 万ウォン) まであり、低所得者は安い賃金で職人を雇う事が可能であることが わかった。

一方、日本の全国の賃金労働者の月収データをみると、中間層が 
厚いことがわかる。全国の月収平均と大工、タイル職人の月収平均 を比較すると、韓国より差が少なく、中間層が職人に工事を依頼す ることが経済的に厳しいことがうかがえる。こうしたことが住宅設 備や家具において部品化の促進につながったと推測される。
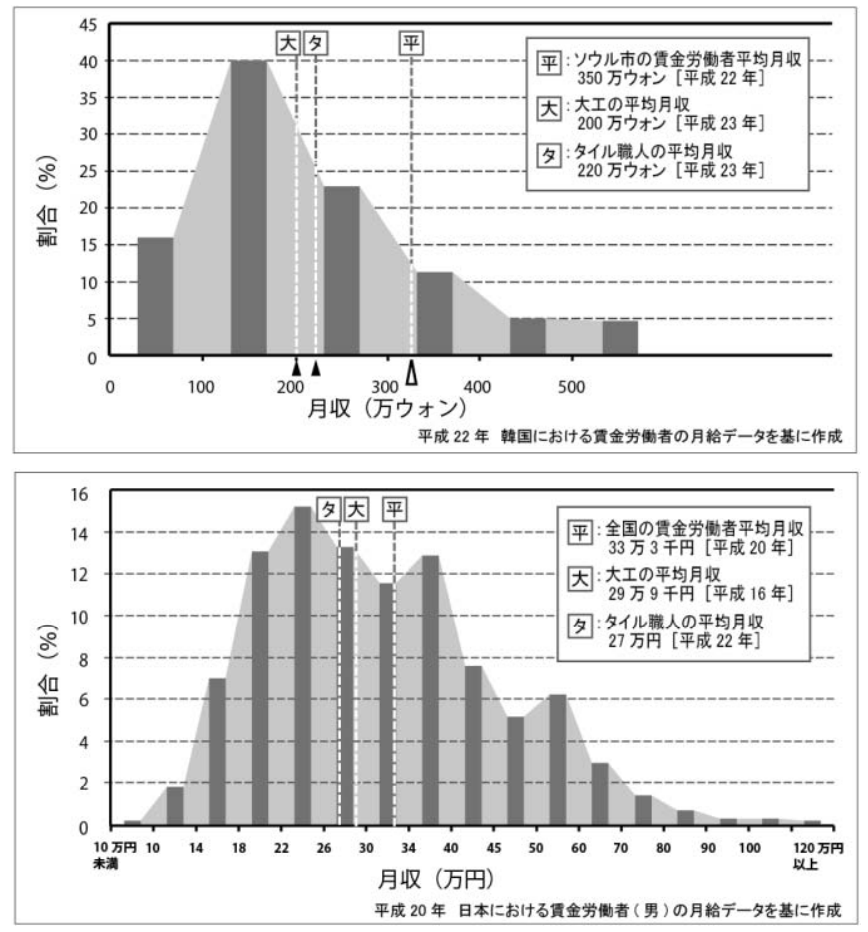

図 11 韓国（上）と日本（下）の所得分布図注13)

\section{5. まとめと今後の課題}

本研究の結論は以下のようにまとめられる。

(1)韓国では 3 段階の個別要求時期において工事を行っている。特に 新築段階の引渡前に内装を完成させた後、内装会社によって入居予 定者の個別要求に対応する方式が定着している。その理由としては、 長期間の建設工事による内装仕様の要求変更、安価な内装工事費用、 同時期内の集中工事による騒音トラブルの防止等が挙げられる。さ らに、施工社が入居予定者への便利を図るために、引渡前の個別工 事を暗黙に許容していることも一つの原因と考えられる。

(2)工事段階によって住戸内のカスタマイズ範囲と工事実施主体に違 いがみられた。

㓍工前のオプション工事では、所有者によるバルコニー拡張工事 やそれに伴う建具や間仕切りの設置および変更が多かった。バルコ ニー拡張が合法化された以後に建設された住戸では、契約時に施工 社にバルコニー拡張のような構造躯体に影響する工事を安全に依頼 できることから、引渡前または入居後に瑕疵が頻繁に発生する個人 業者に依頼しない傾向がある。

一方新築段階の引渡前工事では、所有者により専有部分の仕上げ や設備等にまで工事範囲が広がっている傾向がみられた。これは、 インテリア会社や個人業者に安価に内装工事を一括発注できること が理由として考えられる。

入居後工事では、他の工事段階と比べ、韓国式賃貸のチョンセに住 む賃借人の費用負担で工事を行っており、入居の際に専用インフィ ル部を中心に改修工事をする傾向が多くみられた。この時期には持 ち家、賃貸ともに現居住者自身の負担で工事を行う特徵があり、趣
味や家族の変化等のライフスタイルに合わない場合は再度内装工事 を行うことで、賃借人の定住意識に影響を与えていると考えられる。 (3)システムキッチン等の設備や家具の部品化が進んでおり、改修の 実態からも工業化の進み具合が確認できた。しかし、その一方で、 既製の家具の隙間を職人の手で納めていたり、浴室のタイル交換が 行われていたり、職人による手工業が盛んで、細部まで綺麗な仕上 がりを実現していた。これは、韓国では住宅設備回り部品や家具に おいて、ある程度まで工業化が進みつつも、仕上げの際には職人の 手が介在する『部分的な工業化』が進んでいることがいえる。その 理由として、中堅労働者と職人賃金の格差があり、安価な費用でイ ンフィル工事ができることが考えられる。

本研究は、発展途上国である韓国、インドネシア、ブラジル、中 国と日本の集合住宅の住宅改造と個別デザイン（住宅部品等）の比 較調查を通して、国際的に汎用性を持つ SI 住宅理論を明らかにす るための一連の研究成果である集14)。

今後、続報として韓国におけるバルコニー拡張の実態および共用 部の改修意思決定、関連法制度等について報告する予定である。

\section{謝辞}

本研究の調査にあたり、事例団地の管理事務所所長、施工社、設 計事務所、インテリア会社・個人業者、居住者にご協力を頂きまし た。また、本研究は坂井和紀（千葉大学 2012 年度修士論文）の成 果に負うところが大きい。ここに記して深く感謝の意を表します。

注

注 1) 2010 年住宅総戸数 14677419 戸、単独住宅 4089491 戸、アパート 8576013 戸、連立住宅 536070 戸、多世帯住宅 1314452 戸、非居住用建物内住宅 161393 戸（「2012 韓国統計年鑑」韓国統計庁より引用）

注 2) 共同住宅の定義（建築法施行令より）

アパート：5階建て以上の共同住宅

連立住宅：4 階建て以下且床面積 $660 \mathrm{~m}^{2}$ 超え

多世帯住宅 : 4 階建て以下且床面積 $660 \mathrm{~m}^{2}$ 以下

寄宿舎 : 学校又は工場等の学生又は従業員等のため使用される住宅。共 同炊事等をすることができる構造であり、独立した住居形態を 備えていないもの

注 3）リモデリング（Remodeling）とは、建物の老朽化の抑制または、機能向 上等のために大修繥または大統領令で定める範囲内で増築する行為（住 宅法第 21 条 13)

注 4) 韓国では、ベルコニー部は一般的にサービス面積として扱われ、専有面 積にカウントされず、専有面積の外壁から $1.5 \mathrm{~m}$ までをバルコニーとして 認めている (建築法施行令 119 条)。2005 年 12 月「建築法施行令」の法 改正後の内容として、「バルコニー拡張を行っても延床面積に含まれな いため、使用面積増加に伴う税負担がかからないこと」や「別途に避難 空間を設ければバルコニーは必要ないこと」等が大きな特徴である。

注 5) 参考文献 2) 参照

注 6) 韓国の建設企業 300 社およびデベロパー協会の会員社 68 社を対象にア ンケート調查を行い、70 社から回答があった。そのうち、施行と施工を 全て遂行する企業が $44.3 \%$ であった。参考文献 14) 参照

注 7) 工事完了後、業者が役所に使用承認申請をし、役所（または建築士が業 務代行）が現場確認後、検查済証を発行し、竣工になる。

注 8）施行社とは、開発事業の事業運営者を指寸。デベロッパーとも言う。 (出展 : 韓国不動産用語辞典、ブヨン出版社 (2011) ) 。韓国では施工社 がデベロッパーの業務を兼用することが多い(施工社へのヒアリングより)

注 9）建物の竣工後、施工社は入居予定者の入居指定期間として $1 \sim 2$ ケ月程 度設けている。一般的に景気が良い時は 1 ケ月、最近 (2012 年調査時) は景気が悪く、 2 ヶ月から 3 ケ月の場合がある。この期間中、購入者が 施工社に残金を支払い終えると、すぐ入居しなければならない仕組みに なっている。しかし、入居前にインテリア工事ができないことに不満を 
持つ入居者が多いことから、引渡前の個別工事を許容している。なお、 残金支払い前までは、施工社が住戸の所有権を持つことになる。

注 10） 2004 年以降、住宅法により、分譲アパートの管理内容が具体的に規定 され、行政指導で管理実務を専門家が遂行することが義務付けられてい る。日本のように区分所有者全員による総会を開く義務はなく、区分所 有者の代表で構成される入住者代表会議が管理方式を決定し、管理事務 所を設けて住宅管理士資格を持つものを雇い管理執行機関の代表に選任 して、管理運営を行う。住戸数が 10 戸以上は、管理人の配置〔集合建物 法]、500 戸以上は管理事務所長（住宅管理士・士補）およびスタッフの 配置が義務付けられている[住宅法]。ここでいう管理事務所とは、共同 住宅の管理業務を遂行するように共同住宅団地内に設置された場所を指 寸[住宅建設基準等に関する規定〕。

注 11) 韓国特有の賃貸方式で、一定額の保証金を家主に預けて、契約期間中に 別途の家賃負担なしに家を借りるというシステムである。契約退去時に は、最初に預けた金額を払い戻してもらう。

注 12)グループロ : 現場工事でオーダーメイドの家具を納まる

グループロ：造付家具か寸法調整家具か判別不可能

グループ司：現場工事で既製品を建築と一体的に納める

グループロ：既製品のフレームで納める

注 13) 韓国の所得分布図は、韓国国税統計局の平成 22 年韓国における賃金労 働者の月給データを基に作成。日本の所得分布図は、厚生労働省の平成 20 年賃金構造基本統計調查結果のデータを基化作成

注 14)「研究成果報告書: 発展途上国を含むSI 住宅の国際理論とその実現方 法阅する関研究」（科学研究費補助金・基盤研究（B）、研究課題番号： 22360247)

\section{参考文献}

1）丁志映：韓国のマンション事情一建替えとリモデリング制度の変遷と最新 事例調査-, マンション学, 第 31 号, pp. 42-47, 2008.10

2) Lee Chang-Seok \& Jang Leem-Jong: A Study on the Uses and Expansion of Apartment in the Private Sector, 大韓建築学会論文集計画系, 第 23 巻第 8 号, pp. 107-114, 2007.8

3) Kim Min-Gyu : A Study on the Change of Plan Following Balcony Extension in Apartment, 大韓建築学会論文集計画系, 第 25 巻第 7 号, pp. 149-156, 2009. 7

4) Seo Boong-Kyo \& Choi Jeong-Oh : A Study on Tendency of Extended Balcony Unit Plans of LH Corp, 韓国室内デザイン学会論文集, 第 20 巻 第 1 号, pp. 146-153，2011.2

5) Seong Byeong-Min \& Kim Won-Pil : A Study on Residential Satisfaction with Diversion of Expanded Balcony Area at Multi-family Housing through Residents`Survey, 大韓建築学会論文集計画系，第 27 巻第 11 号, pp. 317-324, 2011.11

6) Kim Sun-Young \& Oh Chan-Ohk:A Study of Current Status and Residents Needs of Balcony Extension in Korea Apartment Housing, 韓国室内デ ザイン学会論文集，第 21 巻第 2 号, pp. 146-153，2012.4

7）江袋聡司・小林秀樹・藤本秀一 : 民間分讓集合住宅におけるフリープラン 設計の実態と課題, 都市住宅学 35 号, pp. 39-44, 2001.10

8）沢田知子・曽根里子・丸茂みゆき：「フリープラン賃貸住宅」 25 年歴にお ける住まい方変化とインフィル変更動向, 日本建築学会計画系論文集第 78 卷第 686 号, pp. 755-764, 2013.4

9）加茂みどり・高田光雄：SI 型集合住宅におけるリフォームに関する研究 その 1 ，日本建築学会計画系論文集第 599 号, pp. 25-32, 2006.1

10) 藤本秀一・新井信幸・小林秀樹 : 公社賃貸住宅団地における自主リフォー ムの実態と一般化に向けた課題, 日本建築学会計画系論文集第 605 号, pp. $7-13,2006.7$

11) 番場美恵子・竹田喜美子 : 集合住宅における経年変化によるリフォーム実 態とシルバーステージの関係, 日本建築学会計画系論文集第 606 号, pp. 25-31, 2006. 8

12) 前田修吾・岩岡竜夫・岩田利枝 : 東京都住宅協会による $3 \mathrm{~K}$ 型分譲集合住 宅のリフォームの実態, 日本建築学会計画系論文集第 75 巻第 647 号, pp. $9-15,2010.1$

13) 南一誠・小柳津醇一・三井所清典 : エステート鶴巻 3 に打けるインフィル の更新実態に関する研究、住宅総合研究財団研究論文集 34 号, pp. 327336,2007

14)キムミンヒョン: 不動産開発事業のリスク要因分析および管理方案-共同 住宅開発事業を中心に一, 韓国建設産業研究院報告集, pp. 1-97, 2005.11

15）丁志映 ・ 坂井和紀 - 田中大樹 - 李東ウック ・ 藤本秀一・米野史健 - 崔在順 金洙岩・小林秀樹：韓国の集合住宅における住戸改修に関する研究 その 1一工事時期によるリフォーム方法と実施内容について-, 日本建築学会大 会学術講演梗概集 E-2 分册, pp. 1267-1268, 2012

16) 久家あか权・坂井和紀 - 李東ウック・丁志映・藤本秀一・米野史健 ・ 小林 秀樹: 韓国の集合住宅における住戸改修に関する研究 その 2-バルコニー 部の拡張による活用実態について-, 日本建築学会大会学術講演梗概集 E2 分册, pp. 1217-1218, 2013

17) 坂井和紀・久家あか放・李東ウック・丁志映・藤本秀一・米野史健 ・ 小林 秀樹 : 韓国の集合住宅における住戸改修に関する研究 その 3-インフィル 部の工業化について-, 日本建築学会大会学術講演梗概集 E-2 分册, pp. 1219-1220, 2013

18) 坂井和紀 : 韓国の集合住宅における住戸改修からみた SI ハウジングシス テムに関する研究，千葉大学修士論文，2013.3 


\title{
A STUDY ON ACTUAL CONDITION OF CUSTOMIZATION OF DWELLING ON THE APARTMENTS IN SOUTH KOREA
}

\author{
Jiyoung JUNG ${ }^{*}$, Dong-Wook LEE ${ }^{* *}$, Costa MARIANNE ${ }^{* * *}$, \\ Hidekazu FUJIMOTO****, Fumitake MENO***** and Hideki KOBAYASHI****** \\ * Assistant Prof., Graduate School of Technology, Chiba University, Ph. D. \\ ** Part-time Worker, Dr. Eng. \\ *** Graduate Student, Graduate School of Technology, Chiba University, M. Eng. \\ **** Head, Ministry of Land, Infrastructure and Transport, M. Eng. \\ ***** Senior Researcher, Ministry of Land, Infrastructure and Transport, Dr. Eng. \\ ****** Prof., Graduate School of Technology, Chiba University, Dr. Eng.
}

\section{PURPOSE OF RESEARCH}

The purpose of this study is to investigate the actual nature of the customization of apartments in South Korea and the usage of interior components and industrialization in these dwellings.

\section{SURVEY METHOD AND OBJECT}

We investigated 34 apartment dwelling units in Seoul City and the Incheon New Capital City in South Korea. Furthermore, we conducted interviews with the directors of the property management company in which the units were situated, construction companies, architectural design firms and interior design companies. The investigation's structure and method were based on the personal demands related to the actual characteristics of the dwelling units, the interview of residents about balcony expansion, drawings made on site, and photography and video of the dwellings and housing estate. We conducted three fieldwork surveys from September 2011 to February 2012.

\section{ATTRIBUTES OF THE CASE STUDY}

The dwellings surveyed were 17 owned and 17 rental properties. The building ages ranged from two to thirty years. In addition, length of residency ranged from under a year to over 15 years. Most of the dwellings had an area of about 30-50 square meters. Also many of the cases were of the nuclear family type.

\section{SURVEY RESULTS}

1) The residents did work in the customization period in all three stages of occupancy of their unit. The method of customizing the dwelling to the desires of the prospective tenants using the services of an interior design company is quite established in South Korea, especially before passing the key to the new tenants. The main reasons for this is to request specific interior changes that require long-term construction work, lower cost and the prevention of construction noise. Furthermore in this way the construction company is allowing covert individual work before passing the keys of the new house to tenants.

2) The scale of the customization work and the skill of workers performing them differed by construction stage. During the period in which the tenant is given options before completion of construction, owners had done a lot of expansion work unto the balcony of the unit. In addition, there were many changes in partitions and the associated fittings. During the period after movein, the tenant performed the repair work at his or her expense, regardless of ownership. Moreover, the residents employed an interior design company for renovation if the unit was unsuitable to their lifestyle.

3) The assembly of furniture and equipment such as a system kitchen is progressing. But craftsmen commonly intervened in the final stages of work. The tenants can perform infill construction at a low cost because there is a disparity in wages between craftsmen and mid-level employers.

\section{FUTURE SUBJECT}

In the future, we plan to report on the decision-making process of common space and balcony extension; and also their related laws and regulations. 